\title{
Evaluation of the $\mathrm{Ni}_{3} \mathrm{Al}$ Base Alloys IC221 and IC218L.Zr
}

\author{
E. Samuelsson, P. W. Keefe \\ Special Metals Corporation \\ New Hartford, NY
}

\author{
R. W. Furgason \\ Ladish Company \\ Cudahy, WI
}

\begin{abstract}
$\underline{\text { Abstract }}$
$\mathrm{Ni}_{3} \mathrm{Al}$-base alloys are being considered for a range of applications, where their high strength at elevated temperatures can be utilized. This paper summarizes the results of physical metallurgy evaluations of IC221 and IC218LZr which are alloys suitable for commercial applications.

Ingot sizes of $406 \mathrm{~mm}$ and $102 \mathrm{~mm}$ diameter were evaluated. Initial solidification in alloy IC218LZr occurs by precipitation of $\gamma$ dendrites. The remaining liquid is enriched in alloying elements, and final solidification occurs by a $\gamma-\gamma^{\prime}$ eutectic reaction, dominated by the $\gamma^{\prime}$ phase. IC221, which has a higher $\mathrm{Zr}$ content, solidifies by the same sequence, except final solidification occurs by freezing of a zirconium-rich eutectic. Energy and wavelength dispersive $\mathrm{x}$-ray analysis indicate that the precipitated zirconium phase is $\mathrm{Ni}_{7} \mathrm{Zr}_{2}$. The reason that $\mathrm{Ni}_{7} \mathrm{Zr}_{2}$ precipitates rather than $\mathrm{Ni}_{5} \mathrm{Zr}$, which would be expected for an alloy containing only 1.8 weight $\% \mathrm{Zr}$, is not fully understood. However, it is probable that the strong interaction between nickel and aluminum leads to a decreased activity of nickel in the interdendritic fluid.
\end{abstract}

Mechanical properties were evaluated at temperatures from $760^{\circ} \mathrm{C}$ to $1038^{\circ} \mathrm{C}$. In this temperature range, the yield strength decreases with temperature and minimum ductility is at approximately $950^{\circ} \mathrm{C}$. Comparative evaluation of compression yield strength indicates that IC221 is approximately $500 \mathrm{MPa}$ stronger than IN718 in the temperature range of $760^{\circ} \mathrm{C}$ to $1038^{\circ} \mathrm{C}$.

This project demonstrates that $\mathrm{Ni}_{3} \mathrm{Al}$ base alloys can be consumably remelted into production-size ingots without deleterious segregation or ingot cracking. 


\section{Introduction}

In recent years the interest in intermetallic alloys, including nickel aluminide alloys, has increased. Numerous articles deal with various aspects of nickel aluminides; some useful review articles are those by Stoloff ${ }^{1}, \mathrm{Pope}^{2}, \mathrm{Sen}^{3}$ and Sikka ${ }^{4}$. Sikka ${ }^{5}$ has also discussed the commercialization of nickel aluminide alloys that were developed by Oak Ridge National Laboratory (ORNL).

This paper deals with properties of the two $\mathrm{Ni}_{3} \mathrm{Al}$ base alloys, IC218LZr and IC221 whose compositions are given in Table I. These alloys have similar compositions except for the higher content of zirconium in IC221. IC218LZr is intended for wrought applications, while IC221 is intended for cast applications. Only as-cast structures and properties of the alloys are evaluated in this study.

The alloy samples evaluated were produced by vacuum induction melting (VIM) followed by consumable electrode remelting. Samples from $102 \mathrm{~mm}$ diameter ingots of both alloys were evaluated, as were samples from a $406 \mathrm{~mm}$ diameter ingot of IC221. The $406 \mathrm{~mm}$ IC221 ingot is believed to be the largest sound, consumable-electroderemelted ingot produced. The macrostructure of it is shown in Figure 1.

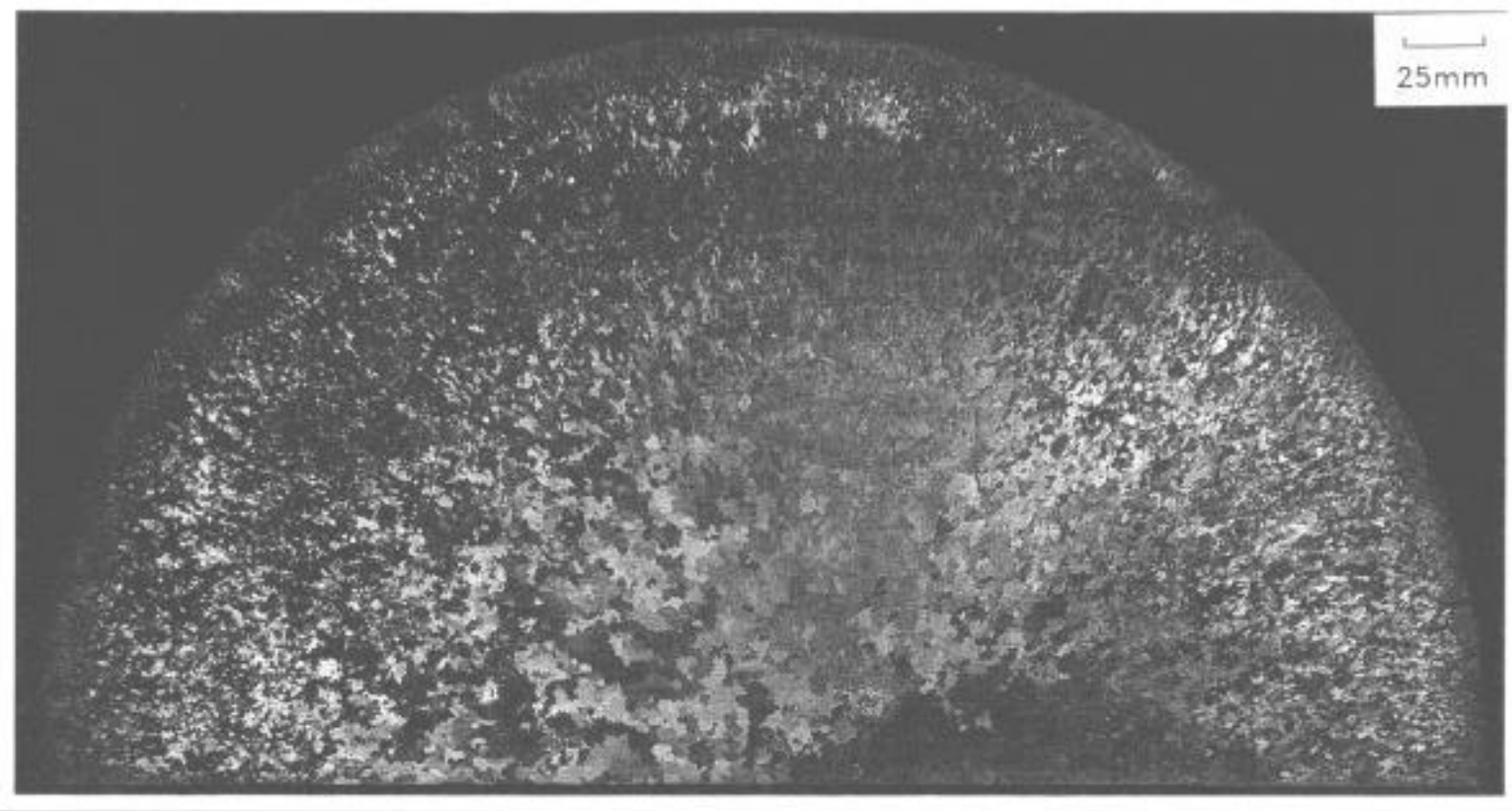

Figure 1 Macrostructure of $406 \mathrm{~mm}$ diameter IC221 ingot. Canada etch.

\section{$\underline{\text { Solidification Sequence }}$}

IC218LZr. Alloy IC218LZr solidifies by initial formation of $\gamma$ dendrites which subsequently precipitate $\gamma^{\prime}$ cubes. The remaining liquid freezes in a "starburst" $\gamma-\gamma^{\prime}$ eutectic reaction. Figure 2 schematically describes the solidification sequence with the corresponding microstructure. The composition of phases, as determined by EDS analysis, is presented in Table II. Qualitatively, these results agree well with those previously published for similar alloys. ${ }^{6}$ 

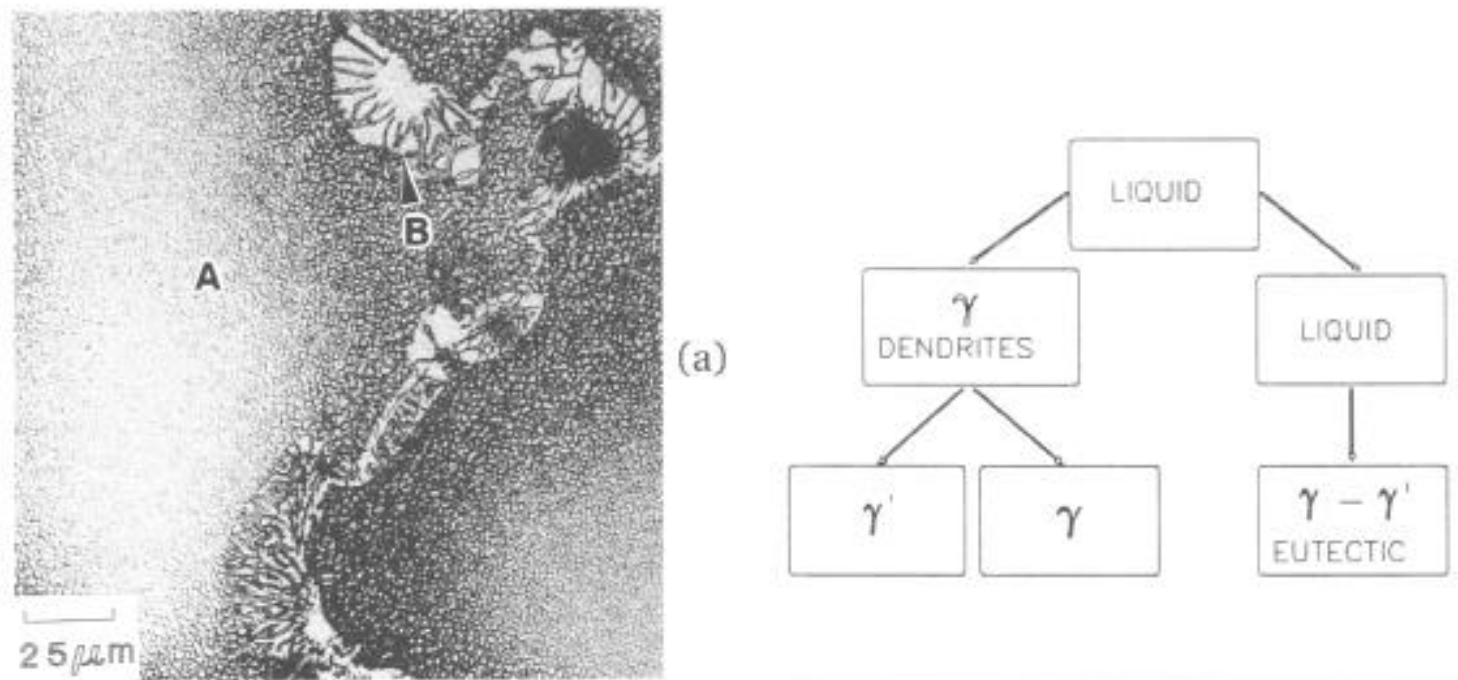

(b)

Figure 2. IC218LZr: (a) As-cast structure: (A) Dendrite, (B) Starburst; Kalling's etch. (b) Schematic solidification sequence.

Table I. Nominal Compositions of IC221 and IC218LZr

\begin{tabular}{|c|c|c|c|c|}
\hline \multirow[b]{2}{*}{ Element } & \multicolumn{2}{|c|}{ Weight \% } & \multicolumn{2}{|c|}{ Atomic $\%$} \\
\hline & IC $218 \mathrm{LZr}$ & IC221 & IC218L Zr & IC221 \\
\hline $\mathrm{Al}$ & 8.7 & 8.5 & 17.0 & 16.7 \\
\hline $\mathrm{Cr}$ & 8.1 & 7.8 & 8.2 & 8.0 \\
\hline $\mathrm{Zr}$ & 0.2 & 1.7 & 0.1 & 1.0 \\
\hline $\mathrm{B}$ & 0.02 & 0.02 & 0.1 & 0.1 \\
\hline $\mathrm{Ni}$ & $\mathrm{Bal}$ & Bal & 74.6 & 74.2 \\
\hline
\end{tabular}

Table II. Composition of Phases in As-Cast IC218LZr as Determined by EDX Analysis (Refer to Figure 2).

Area

Dendrite $(A)$ :

Cube $\left(\gamma^{\prime}\right)$

Intercube $(\gamma)$

Starburst (B):

Cell $\left(\gamma^{\prime}\right)$

Intercell $(\gamma)$
$\underline{\mathrm{Al}}$

10.2

7.2

10.0

7.2
Composition Weight \%

$\underline{\underline{\mathrm{Cr}}} \quad \underline{\mathrm{Ni}} \quad \underline{\mathrm{Zr}}$

7.1

82.5

0.2

8.6

84.2

0

6.0

10.2
$82.8 \quad 1.2$

$82.2 \quad 0.4$

IC221. Alloy IC221 initially solidifies by the same sequences as IC218LZr, as seen in the schematic in Figure 3. However, due to the higher zirconium content, a lower melting point eutectic completes the solidification. The resulting interdendritic structure consists of a $\mathrm{Zr}$-rich phase which co-precipitates with $\gamma$ rods. The $\gamma$ rods appear as a dendritic 

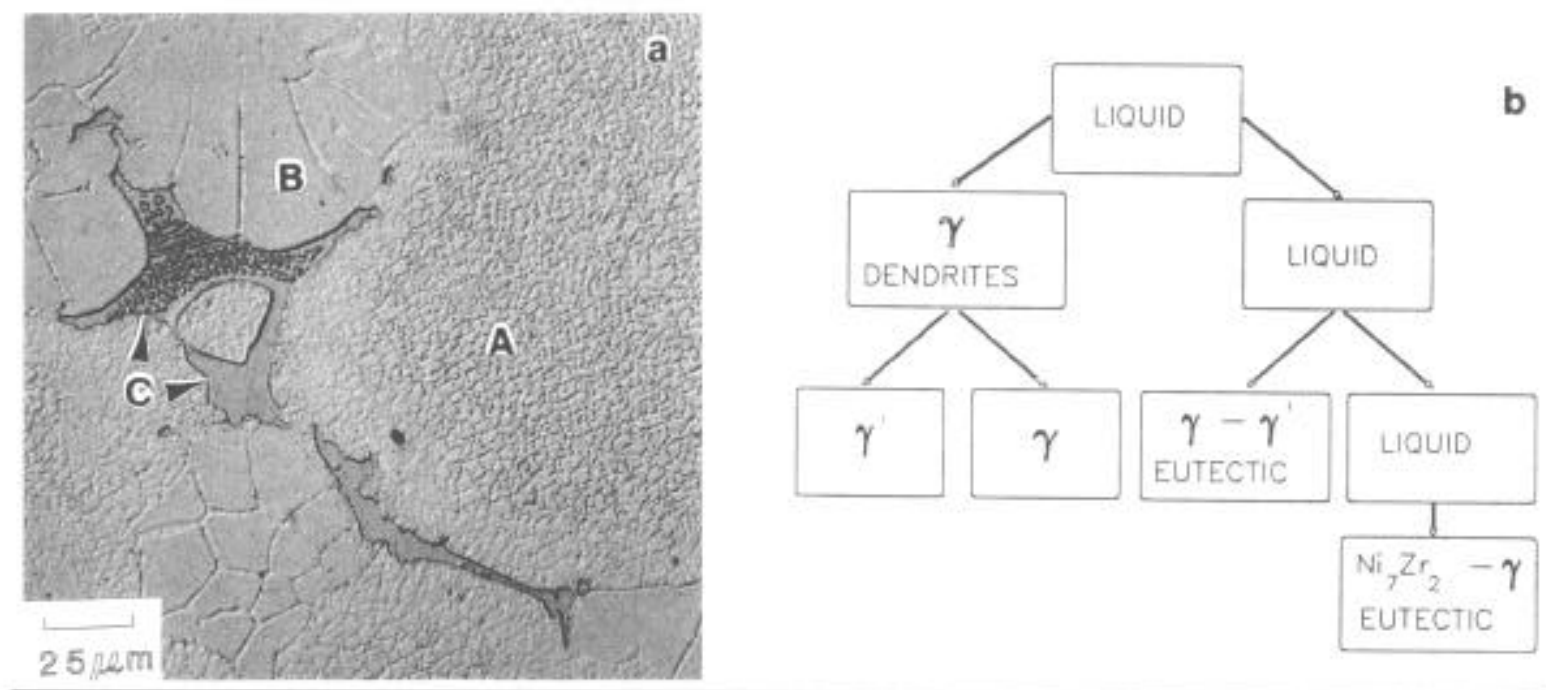

Figure 3. IC221: (a) As-cast structure: (A) Dendrite, (B) Starburst, (C) Eutectic; (Electrolytic etch.) (b) Schematic of solidification sequence.

or dot pattern on metallographic samples (Figure 3a). It was discovered that the $\mathrm{Zr}$-rich phase will etch heavily and leave cavities if aggressive etchants such as Kalling's are used. (Note when comparing the metallographic structures of Figures 2 and 3 that different etchants were used.) To preserve the $\mathrm{Zr}$-rich phase in IC221 and reveal the structure, a mild electrolytic etch was applied ( $20 \%$ sulphuric acid in methanol, $16 \mathrm{~V}$ for $30 \mathrm{sec}$ ). This technique dissolves the $\gamma$ phase at a slightly higher rate, leaving a gentle contrast. The IC218LZr was etched in Kalling's, which results in the $\gamma^{\prime}$ phase appearing white. The composition of the various phases in IC221 is summarized in Table III. The general compositional trends for the $\gamma$ and $\gamma^{\prime}$ phases are the same as for IC218LZr. However, the composition of the $\mathrm{Zr}$-rich phase appears to correspond to the intermetallic phase $\mathrm{Ni}_{7} \mathrm{Zr}_{2}$ by the atomic ratio of $\mathrm{Ni}$ to $\mathrm{Zr}$ detected $(\mathrm{Ni} / \mathrm{Zr}=3.4)$. Similar phases have previously been identified as $\mathrm{Ni}_{5} \mathrm{Zr}^{6-8}$, which is consistent with the $\mathrm{Ni}-\mathrm{Zr}$ binary phase diagram. However, both quantitative EDX analysis at Special Metals and WDX analysis at the University of British Columbia indicate a composition corresponding to $\mathrm{Ni}_{7} \mathrm{Zr}_{2}$. The reason $\mathrm{Ni}_{7} \mathrm{Zr}_{2}$ forms rather than $\mathrm{Ni}_{5} \mathrm{Zr}$ is not fully understood. We speculate that it is due to the strong attraction of nickel to aluminium, which will decrease the activity of nickel in solution, in combination with the strong segregation of zirconium to the interdendritic liquid.

Finally, the $\beta$ phase was not detected in either IC $218 \mathrm{~L}$ Zr or IC 221 contrary to what has previously been suggested for similar alloys. ${ }^{6}$

\section{Microstructure After Heat Treatment}

The effects of elevated temperature exposure were evaluated by differential thermal analysis (DTA) and gradient bar heat treatment of alloy IC221. The DTA curve for IC221 (Figure 4) exhibits two distinct and one weak endothermic reactions. The first reaction, which initiates at $1146^{\circ} \mathrm{C}$ and peaks at $1172^{\circ} \mathrm{C}$, is consistent with an incipient melting reaction. This reaction is clearly associated with the zirconium-containing phase, since the DTA curve for IC218LZr does not exhibit this peak as seen in Figure 5. The second, less well-defined reaction which initiates at approximately $1200^{\circ} \mathrm{C}$, appears to be the result of solutionizing of a broad range of $\gamma^{\prime}$ structures. These two reactions probably overlap somewhat. The third reaction is a classical melting reaction with solidus and liquidus temperatures of $1300^{\circ} \mathrm{C}$ and $1362^{\circ} \mathrm{C}$, respectively. The phase reactions observed by DTA were verified by metallographic evaluation of a gradient bar 


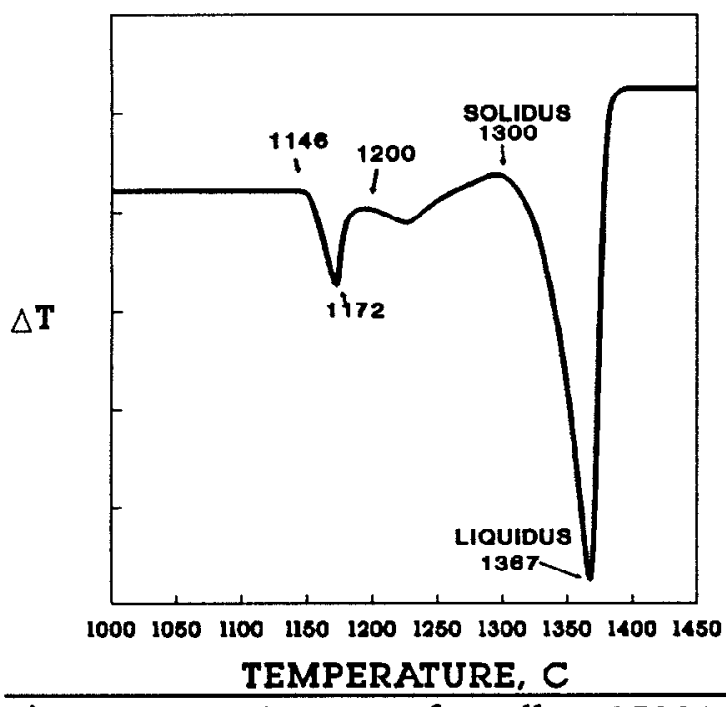

Figure 4. DTA curve for alloy IC221. Heating rate: $10^{\circ} \mathrm{C} / \mathrm{min}$.

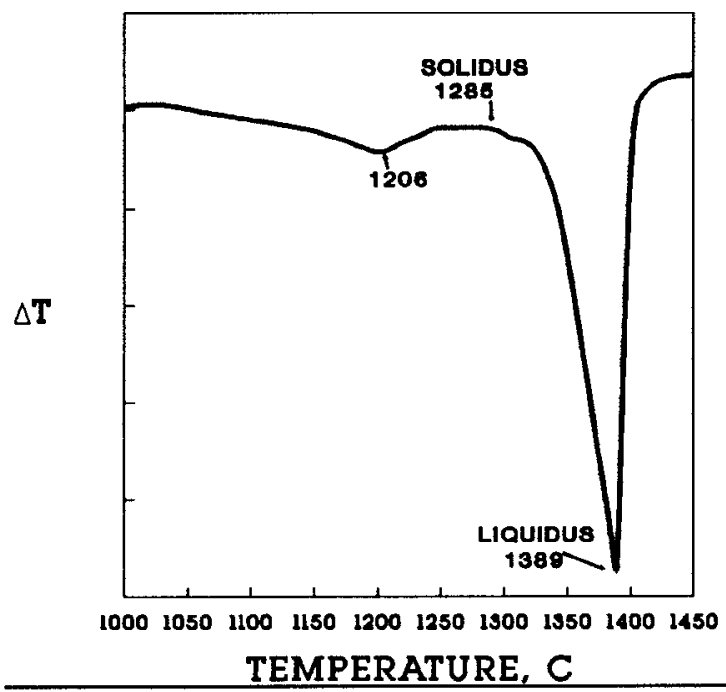

Figure 5.DTA curve for alloy IC218LZr. Heating rate: $10^{\circ} \mathrm{C} / \mathrm{min}$. also tested at a strain rate of $0.005 / \mathrm{min}$. Transverse tensile samples from the $406 \mathrm{~mm}$ IC221 ingot were taken from a slice cut from near the top of the ingot and longitudinal test bars were taken from an adjacent slice. Transverse tensile samples from the $102 \mathrm{~mm}$ IC221 and IC218LZr ingots were taken from slices cut from near the top of the ingots.

Figure 8 shows $0.2 \%$ yield strength versus temperature for IC218LZr and IC221. The results indicate that the yield strength of IC221 in the temperature range of 750 to $1000^{\circ} \mathrm{C}$ is consistently 40 to $70 \mathrm{MPa}$ higher than that of IC218LZr. The IC221 curve closely agrees with results published by Sikka ${ }^{4}$ on cast tubes. Duplicate samples of IC221 (i.e. onc sample from each size ingot) tested at $815^{\circ} \mathrm{C}, 871^{\circ} \mathrm{C}$ and $982^{\circ} \mathrm{C}$ produced essentially identical results. The duplicate samples tested at $760^{\circ} \mathrm{C}$ did, however, show a decrease in yield strength of about $50 \mathrm{MPa}$ for the $406 \mathrm{~mm}$ ingot. This is presumably the result of the slightly coarser grain structure of the $406 \mathrm{~mm}$ ingot as compared to the $102 \mathrm{~mm}$ ingot. Previous work ${ }^{4}$ indicates that the tensile strength of IC221 is fairly sensitive to microstructure at temperatures below $800{ }^{\circ} \mathrm{C}$ and relatively insensitive at temperatures at or above $800^{\circ} \mathrm{C}$. The tensile results also indicate that the ductility of IC221 at temperatures of $750^{\circ} \mathrm{C}$ to $1000^{\circ} \mathrm{C}$ is approximately $15 \%$ better than the 
Table III. Composition of Phases in IC221 as Determined by EDX and WDX Analysis (Refer to Figure 3)

\begin{tabular}{ccccc}
\hline & \multicolumn{5}{c}{ Composition [weight \%] } \\
Area & $\underline{\mathrm{Al}}$ & $\underline{\mathrm{Cr}}$ & $\underline{\mathrm{Ni}}$ & $\underline{\mathrm{Zr}}$ \\
Dendrite $(\mathrm{A}):$ & 8.6 & 7.9 & 83.3 & 0.2 \\
$\quad$ Cube $\left(\gamma^{\prime}\right)$ & 6.0 & 9.2 & 84.5 & 0.3 \\
Intercube $(\gamma)$ & & & & \\
Starburst $(\mathrm{B}):$ & 8.5 & 6.6 & 81.9 & 3.0 \\
$\quad$ Cell $\left(\gamma^{\prime}\right)$ & 5.1 & 10.8 & 83.4 & 0.7 \\
Intercell $(\gamma)$ & & & & \\
Eutectic $(\mathrm{C}):$ & 0.5 & 1.2 & 67.4 & 30.9 \\
Zr-rich phase & 6.0 & 12.2 & 79.7 & 2.1 \\
Rods & & & &
\end{tabular}

ductility of IC218LZr, as seen in Figure 9. These results are not unreasonable, as we are comparing the as-cast properties of an alloy designed for wrought applications (IC218LZr) with those of an alloy designed for casting. The effect of strain rate on the yield strength of $\mathrm{IC} 221$ is presented in Figure 10 . At temperatures above $850^{\circ} \mathrm{C}$, an increase in strain rate from $0.005 / \mathrm{min}$ to $0.06 / \mathrm{min}$ results in an increase in strength of approximately $100 \mathrm{MPa}$. However, samples tested at $760^{\circ} \mathrm{C}$ and $815^{\circ} \mathrm{C}$ did not exhibit any shift in strength. This abrupt change in strain rate sensitivity appears to be the result of the shift in the predominate deformation mechanism from lattice slip to grain boundary slip. Grain boundary slip is a shear process occurring in the direction of the grain boundary, which is promoted by increasing the temperature and/or decreasing the strain rate. ${ }^{10}$
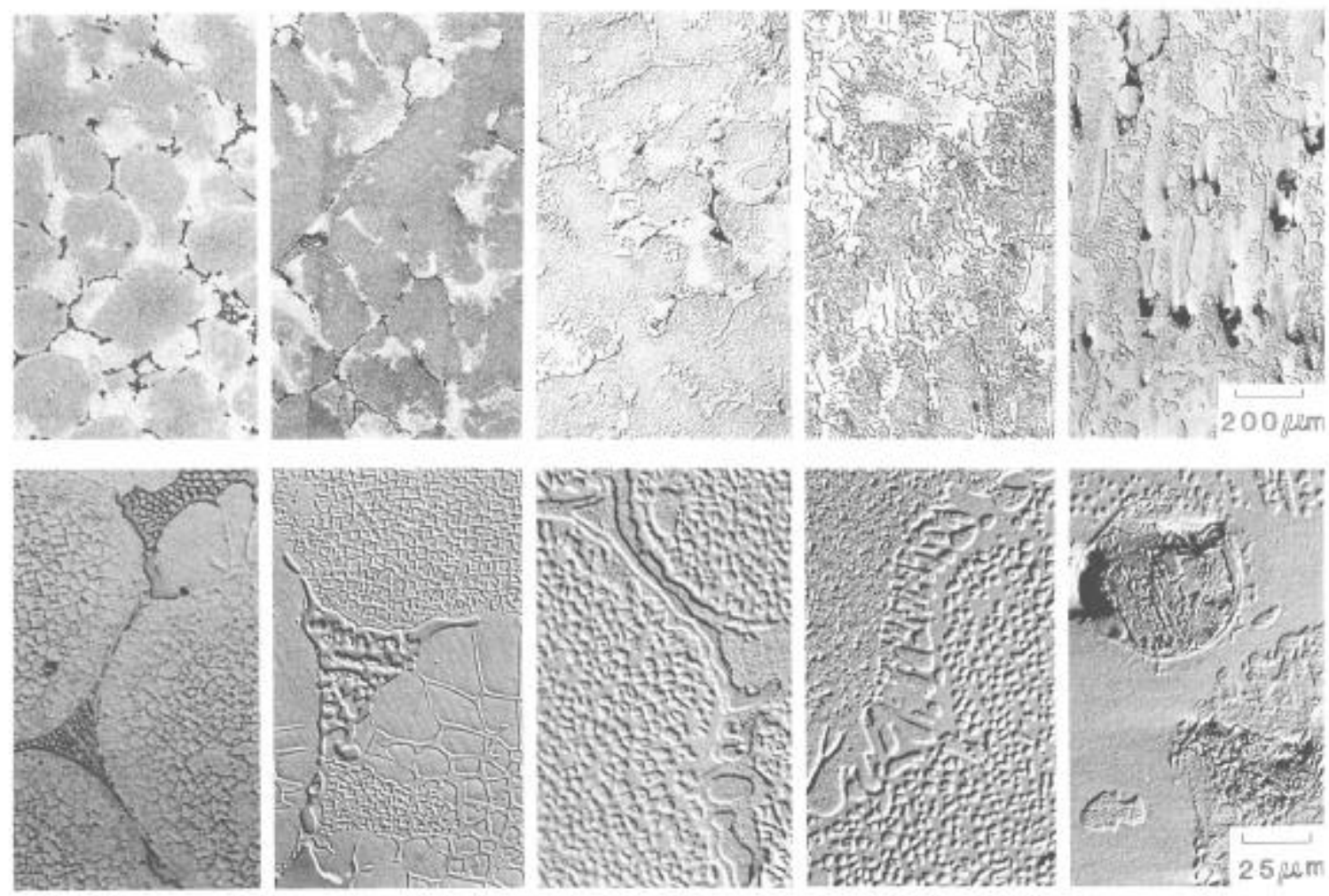

$871 \mathrm{C}$

$1093 \mathrm{C}$

$1121 \mathrm{C}$

$1149 \mathrm{C}$

$1204 \mathrm{C}$

Figure 6. Microstructure of IC221 gradient bar treated for 12 hours and water quenched. Temperatures as indicated. 
Compression Testing. The $406 \mathrm{~mm}$ IC221 ingot was tested in the temperature range between $760^{\circ} \mathrm{C}$ and $1040^{\circ} \mathrm{C}$ to evaluate compressive strength' and between $1093^{\circ} \mathrm{C}$ and $1177^{\circ} \mathrm{C}$ to evaluate hot workability and structural refinement. Longitudinal test bars measuring $10.2 \mathrm{~mm}$ in diameter by $15.2 \mathrm{~mm}$ in height, and test bars measuring $38.1 \mathrm{~mm}$ in diameter by $76 \mathrm{~mm}$ in height were cut from the top of the ingot. The $38.1 \mathrm{~mm}$ samples were isothermally pressed to $50 \%$ of their original height at a constant engineering strain rate of $0.5 / \mathrm{min}$.

Figure 11 is a plot of the 5\% offset yield strength for IC221. IN718 data has been added for comparison. In the temperature range tested, IC221 exhibits approximately a $300 \mathrm{MPa}$ advantage in compressive strength over IN718.

Figure 12 presents photographs of the as-tested surface and the longitudinal macrostructure of samples tested in the temperature range of $1093^{\circ} \mathrm{C}$ and $1177^{\circ} \mathrm{C}$. All samples exhibit severe intergranular cracking which increases with temperature. The macrostructures of the lower temperature tests also exhibit improved grain refinement compared to the samples tested at higher temperatures. Based on this analysis, two additional samples were isothermally pressed under the following conditions:

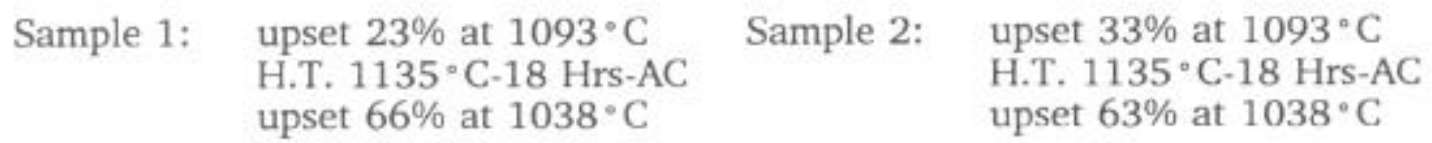

The workability of both samples was greatly improved. Sample 2 contained some light cracks, presumably due to the initial upset. Both samples exhibited a relatively fine structure with the exception of the top and bottom die lock areas. The cross-sectioned macrostructure and general surface condition of sample 1 is presented in figure 13.

\section{Hardness of Gradient Heat Treated Bars}

Two bars from the $406 \mathrm{~mm}$ diameter IC221 ingot were gradient heat treated at $815^{\circ} \mathrm{C}$ to $1260^{\circ} \mathrm{C}$ for four and twelve hours, respectively, followed by water quenching. A third bar of IC221 and a bar of IC218LZr were heat treated at $1149^{\circ} \mathrm{C}$ for four hours, water quenched, then gradient heat treated at $760^{\circ} \mathrm{C}$ to $1093^{\circ} \mathrm{C}$ for twelve hours and water quenched. After preparation, the internal hardness of the bars was evaluated at room temperature. The results are presented in Figures 14 and 15.

The increase in hardness from $930^{\circ} \mathrm{C}$ to $1200^{\circ} \mathrm{C}$ for the gradient heat treated bars is attributed to the solutioning of $\gamma^{\prime}$. It appears that the increase in hardness results from

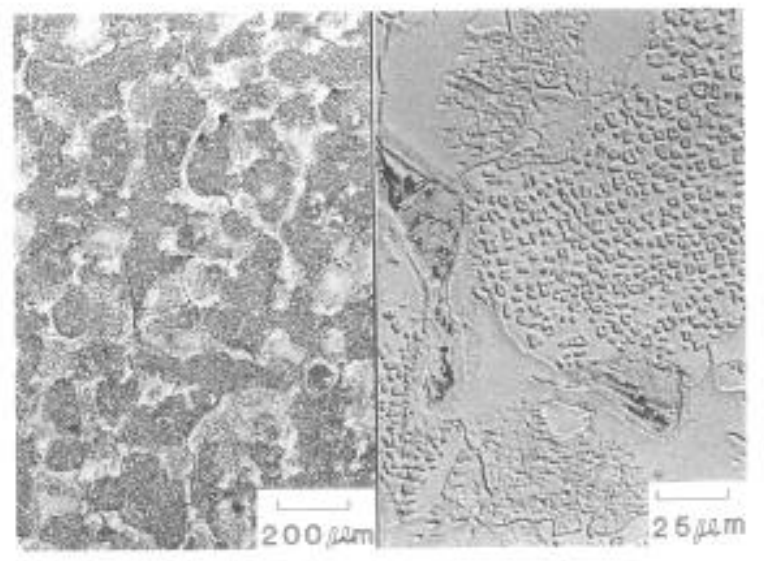

$1180 \mathrm{C} ; 2 \mathrm{~h}$

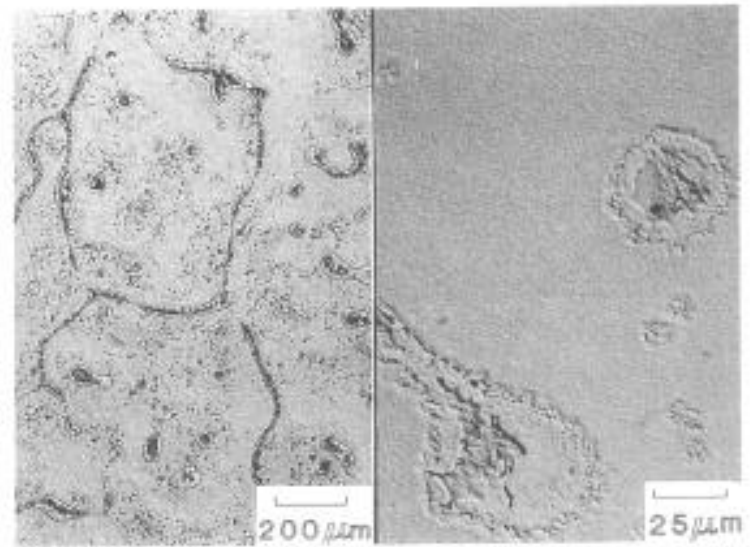

$1250 \mathrm{C} ; 2 \mathrm{~h}$

Figure 7. Microstructure of isothermally treated and water quenched samples of IC221. 


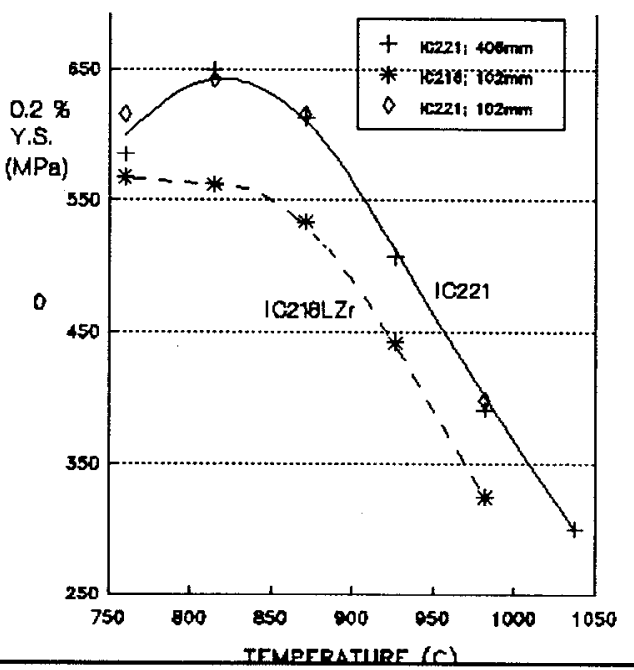

Figure 8. Elevated temperature yield strength of alloys IC221 and IC218LZr.

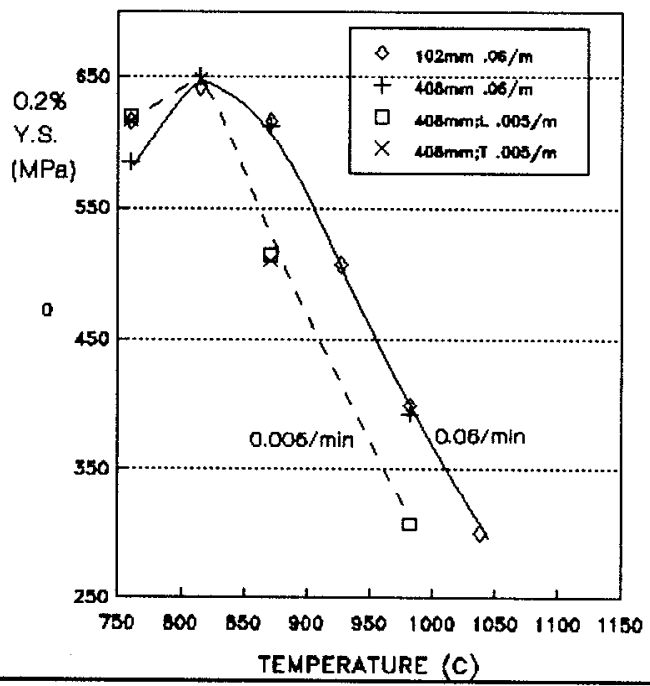

Figure 10. Effect of strain rate on the yield strength of alloy IC221.

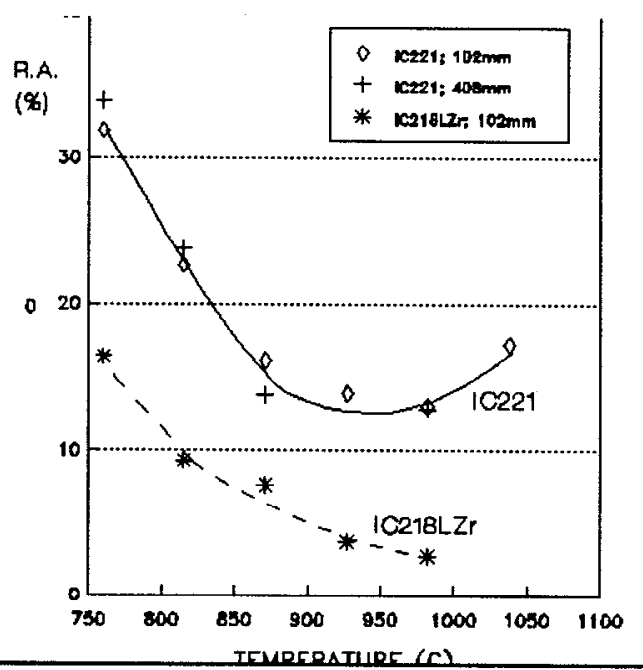

Figure 9. Elevated temperature ductility of alloys IC221 and IC218LZr.

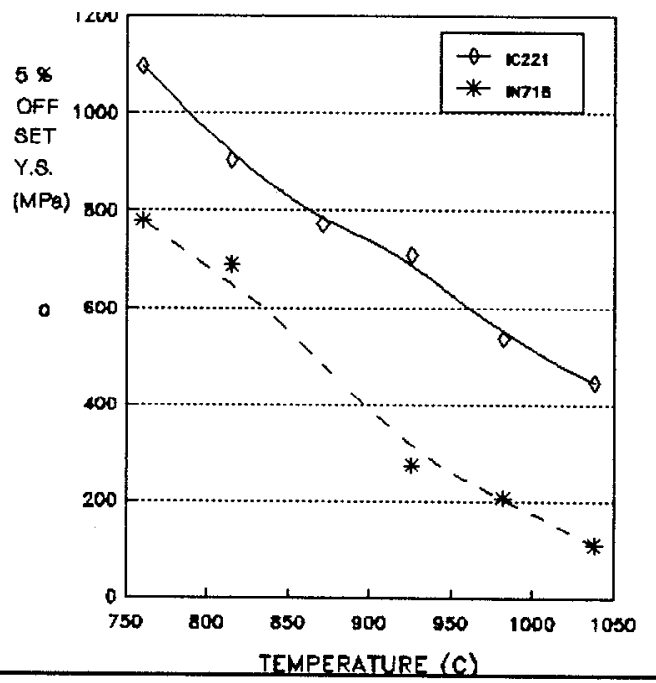

Figure $11.5 \%$ offset yield strength of IC221.

a combination of solid solution hardening and the precipitation of fine cooling $\gamma^{\prime}$ on quenching. The lower hardness of the bar treated for 12 hours could be due either to additional annealing of the matrix or to differences in the initial structure of the bars.

Although the hardness of IC221 and IC218LZr is significantly different as seen in Figure 15 , (results for IC221 are given in Rc and results for IC218LZr in Ra) the shapes of the curves are similar, suggesting the same hardening mechanisms. At $1149 \mathrm{C}$ considerable amounts of $\gamma^{\prime}$ are solutioned while the lower temperatures coarsen existing $\gamma^{\prime}$ resulting in reduced hardness. The minimum hardness is obtained when all $\gamma^{\prime}$ is reprecipitated and overaged. Further reduction in temperature reduces the rate of $\gamma^{\prime}$ coarsening resulting in higher hardness due to aging.

\section{Summary Discussion}

This investigation indicates that production- scale $\mathrm{Ni}_{3} \mathrm{Al}$-base alloy ingots can be produced without unmanageable segregation or ingot cracking. Mechanical test results show that, in spite of severe segregation of zirconium, as-cast IC221 exhibits both better 


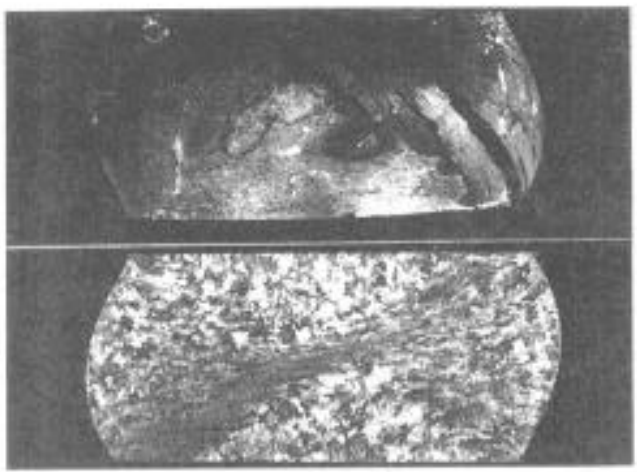

$1093^{\circ} \mathrm{C}$

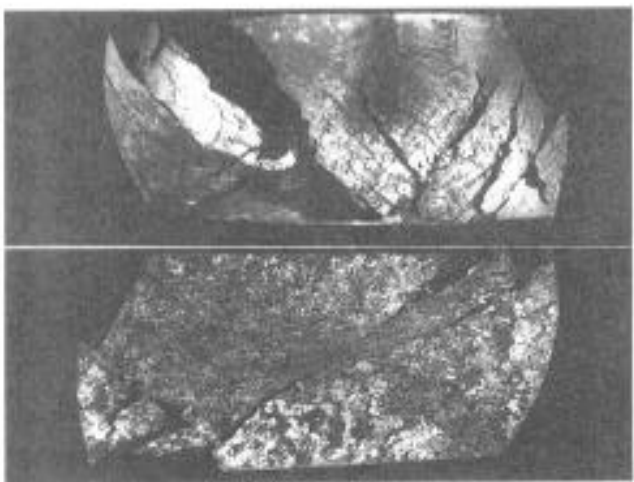

$1149^{\circ} \mathrm{C}$

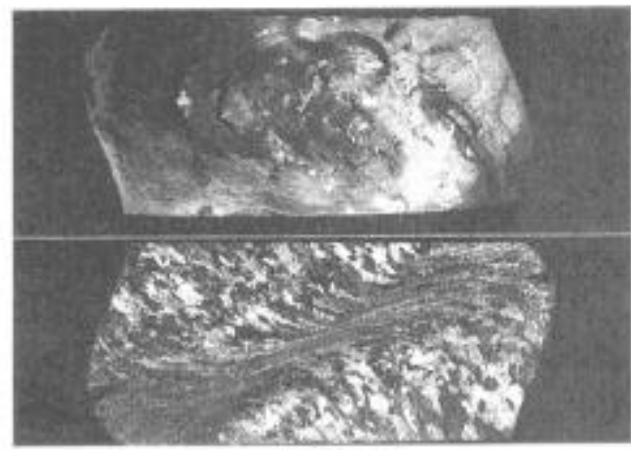

$1121^{\circ} \mathrm{C}$

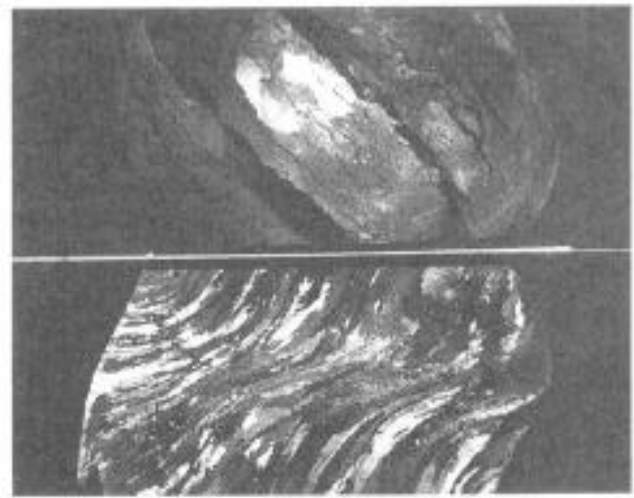

$1177^{\circ} \mathrm{C}$

$17 \mathrm{~mm}$

Figure 12. As-tested surfaces and longitudinal macrostructures of samples isothermally upset at temperatures indicated.

strength and ductility than as-cast IC218LZr, as well as better compressive strength than IN718 at temperatures from $750^{\circ} \mathrm{C}$ to $1000^{\circ} \mathrm{C}$. Heat treating results indicate that the alloys can be homogenized and that the room temperature mechanical properties can be changed through heat treatment. Additional development is needed to fully understand and utilize the heat treatment responses.
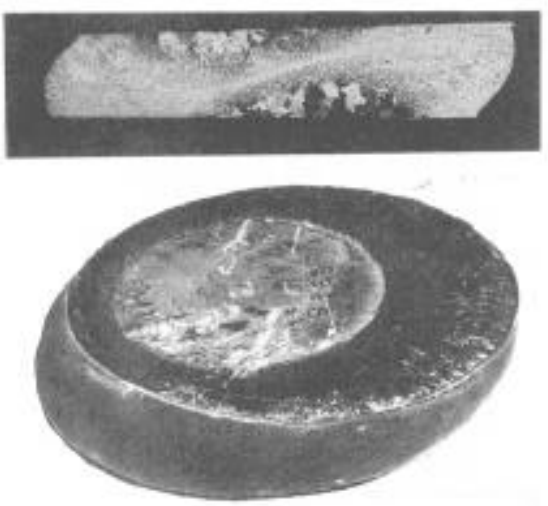

$17 \mathrm{~mm}$

Figure 13. As-tested surface and longitudinal macrostructure of Sample 1.
From a fundamental point of view, the results obtained show the presence of $\mathrm{Ni}_{7} \mathrm{Zr}_{2}$ in IC221 rather than $\mathrm{Ni}_{5} \mathrm{Zr}$, as would be expected from the binary phase diagram. While the reason for the formation of $\mathrm{Ni}_{7} \mathrm{Zr}_{2}$ is not fully understood, we speculate that it is due to the strong attraction of nickel to aluminium which leads to reduced nickel activity in combination with heavy segregation of zirconium to the interdendritic fluid.

\section{Acknowledgements}

The support of the personnel of Ladish and SMC in producing and evaluating the material, as well as in preparing the manuscript is gratefully acknowledged. We also thank Alec Mitchell and Al Schmaltz of the University of British Columbia for their assistance with WDX analysis and technical discussions. 


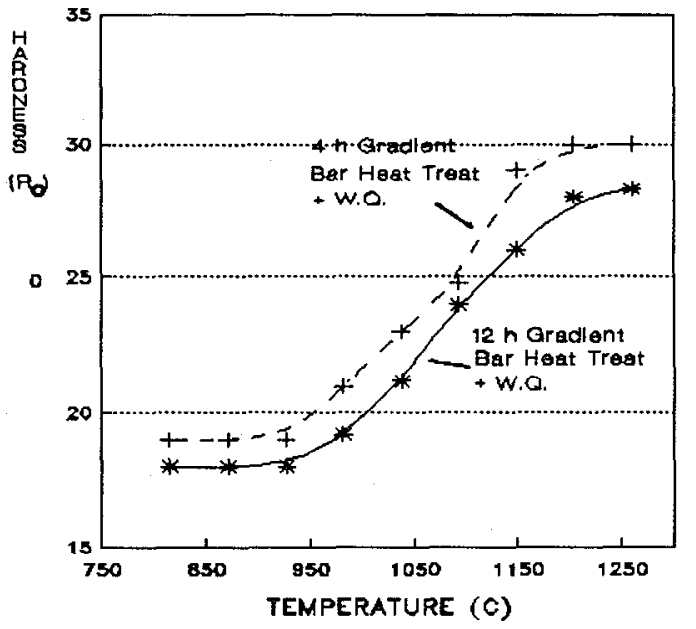

Figure 14. Room temperature hardness of gradient bars.

References

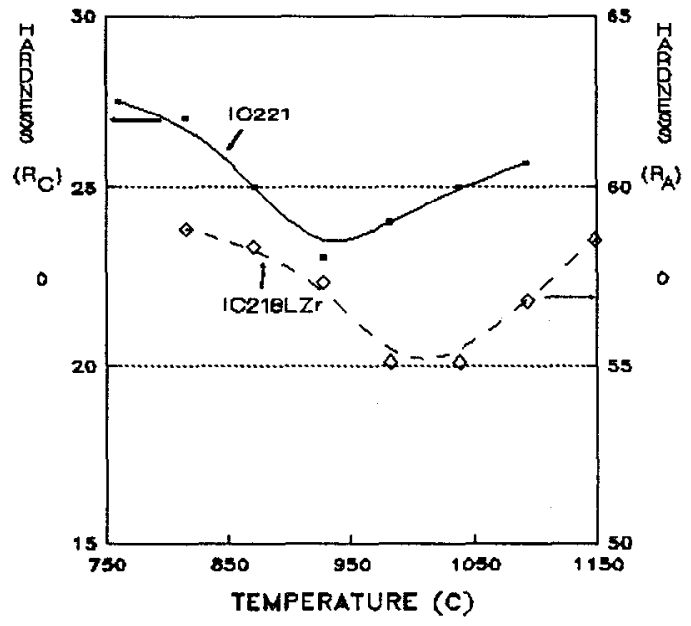

Figure 15. Room temperature hardness of bars $1149^{\circ} \mathrm{C}-4-W Q+$ gradient heat treatment.

1. N. S. Stoloff, "Physical and Mechanical Metallurgy of $\mathrm{Ni}_{3} \mathrm{Al}$," International Metallurgical Review, 34 (4) (1989), 153-183.

2. D. P. Pope and C. T. Liu, "Strength and Ductility of Intermetallic Compounds," Superalloys, Supercomposites, and Superceramics, (Academic Press, 1989) 583-624.

3. S. Sen and D. M. Stefanescu, "Melting and Casting Processes for High-Temperature Intermetallics, $\underline{\mathrm{JOM}}, \mathrm{May}, 1991,30-34$.

4. V. K. Sikka and E. A. Loria, "Industrial Scale Processing and Elevated Temperature Properties of $\mathrm{Ni}_{3} \mathrm{Al}-\mathrm{Cr}-\mathrm{Zr}-\mathrm{B}$ Alloys," Superalloys 1988, (Warrendale, PA: The Metallurgical Society, 1988), 203-212.

5. V. K. Sikka, "Commercialization of Nickel Aluminides," High Temperature Aluminides and Intermetallics, TMS 1989, 505-520. Symposium on High Temperature Alumindes and Intermetallics.

6. C. T. Ho, C. J. Cheng, and J. A. Sekhar, "Solidification Microporosity in Directionally Solidified Multicomponent Nickel Aluminide," Metallurgical Transactions A, 22A (1991), 225-234.

7. Z. Yunrong, W. Yuping, Z. Jizhon, P. Caron, and T. Khan, "Effect of Chemistry Modifications and Heat Treatments on the Mechanical Properties of DS MAR-M200 Superalloy," Superalloys 1988, (Warrendale, PA: The Metallurgical Society, 1988), 335344.

8. T. H. Chuang and Y. C. Pan, "On The Mechanisms of High-Temperature Intergranular Embrittlements of $\mathrm{Ni}_{3} \mathrm{Al}-\mathrm{Zr}$ Alloys," Metallurgical Transactions A, 23A (1992), 1187 1193.

9. P. Nash and C. S. Jayanth, "The Ni-Zr System," Bulletin Alloys Phase Diagrams, 5 (2) (1984), 144-148.

10. G. E. Dieter, "Mechanical Metallurgy," (McGraw-Hill, Inc. 1976), 460T 